\title{
PROFESSIONAL TRAINING OF FUTURE SKILLED WORKERS IN PROFESSIONAL (VOCATIONAL) EDUCATION SCHOOLS BASED ON MODULAR ÀND COMPETENCE APPROACH
}

\author{
Tetiana Herliand \\ Candidate of Pedagogical Sciences (Ph.D), Senior Researcher Fellow Laboratory of Professional Training Technologies Institute \\ of Vocational Education and Training of NAES of Ukraine \\ http://orcid.org/0000-0002-7991-0431, e-mail: Alfina_G@ukr.net
}

\begin{abstract}
Relevance: in order to implement the effective personal self-realization of the future skilled worker, there is a need for the system of professional (vocational) education to follow the changes in the sphere of work, respond to the economic situation in the country, the structure of the market of professions, the demand for new competences. All this requires a significant increase in the degree of flexibility of this education system, creation of fundamentally new forms of its interaction with the labor market, employers (social partners) and their active participation in its further and future development.

Purpose: to carry out theoretical and methodological substantiation of the system of professional training of future skilled workers in the professional (vocational) education schools on the basis of modular competence approach.

Methods: theoretical analysis, study of regulatory documents, analysis of curricula - to find out the state of development of the problem and determine the directions of research; comparison - to study different scientific perspectives on the problem; analysis and synthesis - to develop criteria and indicators of the readiness of future skilled workers to carry out professional activities on a modular basis; systematization and generalization - to formulate conclusions.

Results: the essential characteristics of module competence training are revealed, its peculiarities and main aspects are characterized, which create the proper conditions for the formation of key competences and successful training of future skilled workers, the development of their creative cognitive activity and independence in terms of modular mastery of professional activity.

Conclusions: in the implemented professional training of future skilled workers, based on modular competence, there is a complex development of skills and knowledge within the framework of formation of the specific competence of the individual, which ensures the fulfillment of the specific labor function and reflects the requirements of the modern labor market.
\end{abstract}

Keywords: competence, module, modular competence approach, module technology, vocational education.

Introduction. The gradual entry of the Ukrainian economy into market mechanisms makes it clear that graduates of institutions of professional (vocational) education, without sufficient professional qualification and experience of practical activity, have particular difficulties in adapting to the labor market. In the conditions of dynamism of market relations, vocational training can not guarantee a graduate a job (not only throughout his life, but also in the near future). A large number of young people have to re-study, that is, to acquire a new profession. Today, effective personal self-realization requires not only professional, but also social, economic, communicative competences that accompany, virtually, all types of professional activity. The consequence of these changes is the need for the system of professional (vocational) education to follow the changes in the sphere of work, respond to the economic situation in the country, the 
structure of the market of professions, and the demand for new competences. All this requires a significant increase in the degree of flexibility of this education system, creation of fundamentally new forms of its interaction with the labor market, employers (social partners), their active participation in its further and future development.

Sources of research. Considerable attention is given to the professional training of future skilled workers, and, in particular, its modular competence basis, in the works of numerous Ukrainian (E. Kachan, S. Kravets, N. Kulalaieva, V. Radkevich, etc.) and foreign (I. Zimnyaya, Y. Konovalova, G. Selevko, N. Yusufbekova, etc.) scientists. The modular competence approach used in the training of skilled workers in the construction and machine building industries is relevant today (P. Luzan, M. Mykhniuk, G. Lukianenko, T. Piatnychuk, V. Yahupov, etc.).

However, despite the increased efforts of scientists to study the individual elements of the modular competence framework of professional training of future skilled workers, a comprehensive study (that would meet the requirements of today) has not been properly carried out.

Research methods: theoretical analysis, study of normative documents, analysis of training programs - in order to find out the current state of development of the identified problem and determine the directions of study of professional training of future skilled workers on the modular basis; comparison - to study the diverse scientific perspectives on the problem of this training; analysis and synthesis - to justify the components of the system of professional activity of future skilled workers on the modular basis; systematization and generalization - to formulate scientific conclusions of the problem study.

The purpose of the paper is to carry out theoretical and methodological substantiation of the system of professional training of future skilled workers in the professional (vocational) education schools on the basis of modular competence approach.

Results and discussion. The modernization of production puts forward new demands on skilled workers with vocational education. Increasing the share of work, associated with the implementation and maintenance of new technologies, requires not only practice-oriented and appropriate knowledge of new equipment, tools, but conditions of technological process implementation. Businesses are more interested in saturating all branches of production with workforce with creative capabilities, analytical skills, a tendency to find something new in their field of activity, initiative and social responsibility for the results of work. As a matter of fact, as I. Zimnyaya (2004) notes, it is about strategic personnel policy, in which the necessity of constant updating of knowledge and development of new professions and specialties by future skilled workers are put forward as the basic principles of labor activity.

These are the most pressing issues for the system of professional (vocational) education, as today one of the most "mutually beneficial" areas of interaction between production and education is the participation of employers in the development of contents of dual education (according to sociological studies, more than $80 \%$ of employers are ready for this work). If the participation of employers in the development of the contents of this education provides training in accordance with the tasks of technical modernization and development of the enterprise, improving labor productivity and quality of products, a number of requests of specific production allows professional (vocational) education to prepare competitive professionals in demand in regional labor markets (Luzan et al., 2015).

Therefore, in the conditions of modernization of such production there is an urgent need to use graduates of professional (vocational) educational institutions in particularly difficult working professions, since the management of high-tech automated systems for the production of complex high-precision and expensive products is becoming the main professional function of modern skilled workers.

The concept of "competence" is defined in the existing standards of professional (vocational) education as the ability to apply knowledge, skills and personal qualities for successful activity in the particular field. It is the level of conformity of individual indicators (learning outcomes) that is the main indicator of competence for the employer and society. The essence of the competence approach is that in the process of education a person must form and possess a complete social and professional quality, which allows him to solve industrial problems successfully and interact with other people. Thus, competence is the most adequate to describe the results of professional (vocational) education, which underpin the needs of the modern labor market (Yahupov, 2014).

A competence-based approach to learning is understood as a system of educational construction that aims to form certain key competencies of the student. In professional education, it is a model of organizing such a process, in which the purpose of learning is a set of key competences of students, and as a means of achieving it - the modular construction of the structure and contents of vocational training. It is a requirement of the standard of professional (vocational) education, as the basis of such a standard of the third generation is a modular-disciplinary approach. From this definition it follows that the modular competence 
approach envisages the organization of the training and production process, the purpose of which is the formation of specific competences of future skilled workers, and the contents of this process is structured in the form of models (Luzan, 2012).

Modular construction of such standards has advantages, in particular:

- flexibility (if necessary, it is possible to update or replace specific modules based on the requirements of graduate training);

- the ability to combine the necessary modules and their individual units to individualize learning;

- changes in the assessment procedure - demonstration of the acquired knowledge and skills in the specific module (mastery of competence).

Within the modules there is also a comprehensive development of theoretical and practical aspects of each type of professional activity. At the same time, the contents of theoretical disciplines is reviewed for the redistribution of the amount of necessary theoretical knowledge, which will be the basis for the formation of professional competence, while the "elimination" of superfluous theory will occur (Pankov, 2003).

The training module (represented by the logical completed part of the training material, a certain unit of study) is relatively independent and holistic, having:

- contents in the form of the logically completed block(s) that combine several topics;

- its own learning objectives, the holistic set of which is to be mastered, the ability, knowledge, attitudes and experience (competencies), described in the form of requirements, which must be met by the student of the professional (vocational) educational institution upon completion of the module, and is an integral part of the more general professional function;

- technological and methodological "equipment" that provides the educational process;

- organizational forms of training necessary for its successful implementation;

- control.

The construction of the training module includes the following steps:

- definition of competences that are formed in the process of specific study of the module;

- selection of educational elements of the module - definition of contents, establishment of internal and intersubject links, compilation of supporting notes, diagrams, electronic textbooks;

- defining the tasks of the module element, its key competences;

- design of the didactic process (development of the system of training tasks, materials for practical classes, compiled under the level of knowledge, skills, competences, selection of appropriate techniques for their mastering);

- development of extracurricular independent activity (implementation of tasks according to the algorithm, different-level differentiated problems of problematic nature);

- general element - conclusions, main results;

- development of the system of current and intermediate control of different levels with the freedom of choice and use of the rating system.

The implementation of the module competence approach also involves the development of: module programs that reflect the basic requirements for interdisciplinary courses and planned professional activity; educational and methodological materials that integrate theoretical and practical training in their structure; a system of internal and external controls for assessing the quality of training applied in accordance with the relevant principles and mechanisms. Each module should reflect the planned learning outcomes, its contents (performance and assessment criteria), teaching methods. The limits of the module in its development are determined by a set of theoretical knowledge and practical skills that the student must demonstrate after completing the study module. Competence criteria can be divided into two groups - objective and subjective (external and internal). The procedural features of the activity (pace, speed, intensity, amount) are the objective parameters of the assessment of competence manifestation; a variety of techniques and actions when performing the proposed tasks; efficient indicators of activity- the level and quality of results. Subjective criteria include substantive characteristics of the activity (internal motivations, attitudes, motives of behavior); degree of expressiveness of motives, needs of activity, etc.

Thus, the leading concept of competence approach today is an "educational module", while competence (in one or another professional field) is a set of such modules, and each of them is formed as a specific function (aspect) of future professional activity of the skilled worker. Therefore, in vocational education the competence approach is transformed into modular competence. Under the conditions of modular competence approach within the separate module (being as a unit of education standard for the specialty or educational program of an educational institution), the complex development of skills and knowledge is carried out within the framework of competence formation, which ensures the fulfillment of the specific labor function, taking into account the requirements of the labor market (Luzan et al. , 2015).

Activities on the development of professional programs based on the modular competence approach, possess the necessary logics, consistency, transpar- 
ency, provide continuity with the national didactic tradition, which is well known and widely used in the world practice. These activities have taken place for more than ten years. They are a set of documents that reflect the contents of vocational education and consist of a set of modules aimed at mastering certain key competences needed for achievement of qualification in profession or specialty (Kulalaieva and Herliand, 2018).

In the modular competence approach, the implementation of the educational program foresees:

- introduction of new educational technologies and principles of organization of educational and production process, ensuring effective implementation of new models and contents of vocational education, including using modern information and communication technologies;

- use of interactive forms of conducting classes (seminars in dialog mode, discussions, computer simulations, business and role-playing games, analysis of specific situations, psychological trainings, etc.) in combination with extra-curricular work in order to form and develop students' professional skills;

- organizing meetings with representatives of companies, state and non-governmental organizations, workshops of experts and specialists within the curriculum;

- within the educational process - creation of conditions for students to develop experience of independent decision of cognitive, communicative, organizational, moral and other problems (Yahupov, 2014).

The modular competence approach allows to implement the integration of theoretical and practical learning, rethink the place and role of theoretical knowledge in the process of mastering key competences. The advantage of competence-based modular programs is that their flexibility allows to update or replace individual specific modules when changing specialist requirements, (thereby ensuring the quality of their training at a competitive level). These programs also give an opportunity to individualize training by combining modules. Using a module competence approach to specialist training allows the institution to become the owner of the training intellectual resource. The advantage of these programs for the educational institution is that their tasks meet the needs of employers, real preparation of students for work, contribute to the growth of trust of social partners, the formation of industrial culture in the educational institution, the creation of standard, objective, independent conditions for quality assessment, development of training programs (Herliand et al., 2019).

The technology of implementation of the module competence approach in professional (vocational) education is carried out in stages: at the first stage the development of the modular program (reflecting the basic requirements and the planned professional activity of student); the second stage is the development of teaching and methodological materials for students, teachers, vocational instructors based on the structure of the module and the proposed level of competence; at the third stage - the development of the system of quality assessment of training, taking into account the relevant principles and mechanisms (Fig. 1).

Consequently, the conceptual basis of modular learning is the theory of personality and motivation; activity and its subject; activity, cognitive activity and creativity; gradual formation of mental actions. The aim of the modular competence approach is to create the right conditions for the formation of key competences and learning success, the development of creative cognitive activity and independence of students. The main idea of this approach is to create the right conditions for achieving high and continuous learning outcomes of students as well as developing their creative potential. Such conditions are modular organization of the educational process, constant monitoring of the level of achievements and evaluation of success. We believe that the modular competence approach, provided that it is properly applied, can be a means of forming the key competences of future skilled workers because of its essential features: modularity, competence, rating. These traits create opportunities for competence formation, since the main focus is on the formation of students' ability to learn on their own, self-acquire knowledge, skills and build on skills - categories within the concept of "competence". Individualization of training solves the urgent task - training specialists who are able to adapt quickly to changes in production, make the right and quick decisions and solve the tasks. The

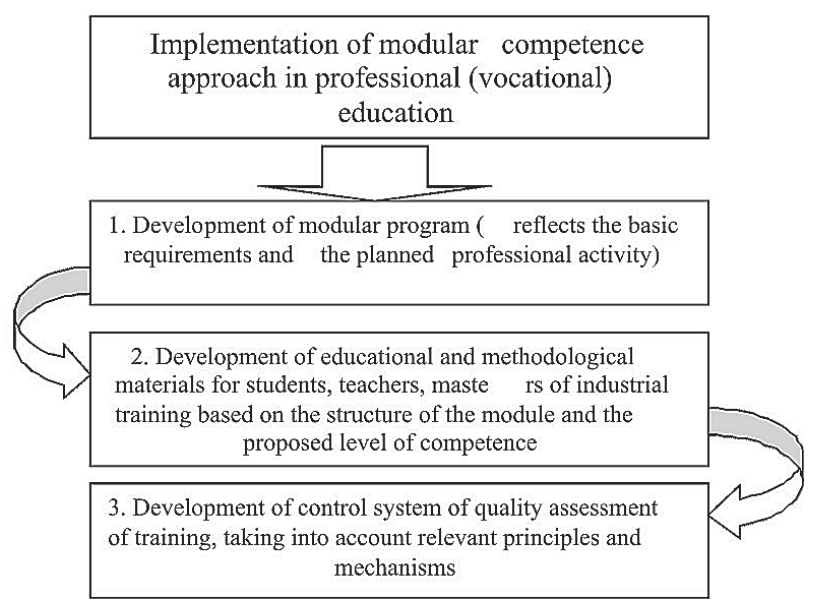

Fig. 1. Technology of implementation of modular competence approach in professional (vocational) education) (designed by O. Oleinikova) 
cooperation of educational institutions with employers in assessing the level of formation, for a example, of the professional competence of the future specialist and determining the requirements for his specific production, is the most in-demand. Students can try their professional skills in different areas of work, which promotes the acquisition of practical competences and increases the competitiveness of graduates (Oleinikova, 2010).

Conclusions. Thus, in professional (vocational) education, the competence approach is transformed into the modular competence, in which (within a single module) a complex development of skills and competences (within the framework of the formation of the specific competence of the individual) is carried out. This specific competence of the individual ensures the fulfillment of the specific labour function and reflects the requirements of the modern labor market. To sum up, it can be noted that the important peculiarity of the modular competence approach is the detailed-planned, diagnostically determined goal of education (training) to develop criteria for assessing the quality of the given educational results. This is especially noticeable in dual training.

\section{List of references}

Зимняя, И. А., 2004. Ключевые компетенциии как результативно-иелевая основа компетентностного подхода в образовании: авторская версия. Москва: Исследовательский центр проблем качества подготовки специалистов.

Герлянд, Т. М, Дрозіч, І. А., Кулалаєва, Н. В., Романова, Г. М. та Шимановський, М. М., 2019. Організаиія дуальної форми навчання у закладах професійної (професійно-технічної): практичний посібник. Житомир: Полісся.

Кравець, С. Г., Кравець, Ю. І., Дерев’янко, Н. П. та Оліферчук, О. Г., 2014. Педагогічні основи формування змісту підготовки кваліфікованих робітників за інтегрованими професіями: посібник. Київ: Поліграфсервіс.

Кулалаєва, Н. В. та Герлянд, Т. М., 2018. Дуальна форма навчання - запорука якісної підготовки сучасного кваліфікованого робітника. Професійно-технічна освіта, 4, с. 40.

Лузан, П. Г., 2012. Реалізація компетентнісного підходу в професійній освіті: технологічний аспект. Науковий вісник Інституту професійно-технічної освіти НАПН України. Професійна педагогіка: зб. наук. праць. / Інст-т проф.-тех. освіти НАПН України, 4, с. 5-11.

Лузан, П. Г., Ягупов, В. В., Лук'яненко, Г. І., Пятничук, Т. В. та Михнюк, М. І., 2015. Модульно-компетентнісний підхід у підготовиі кваліфікованих робітників будівельної та машинобудівельної галузей: монографія. Київ: ІПТО НАПН України.

Олейникова, О.Н., Муравьева, А.А., Коновалова, Ю.В. та Сартакова, Е.В., 2010. Модульные технологии: проектирование и разработка образовательных программ: учеб. Пособие. Москва: Альфа-М; ИНФРА-М.

Паньков, Д. В., 2003. Організація модульної підготовки працівників у відповідності з вимогами ринку праці. Проблеми інж.-пед. Освіти, 5, с. 260-266.

Ягупов, В. В., 2014. Модульно-компетентнісний підхід до професійної підготовки майбутніх кваліфікованих робітників будівельної та машинобудівної галузей. Науковий вісник Інституту професійно-технічної освіти НАПН України. Професійна педагогіка, 7, с. 19-26.

Bazyl, L. O., Shatkovska, H. I., Klymenko, M. M., and Radkevych, V. O., 2019. Psychological and pedagogical features of the career growth of vocational education's teachers. Opcion, 35 (Special Issue 23), 763-779.

\section{Translated \& Transliterated}

Zimnyaya, I. A., 2004. Klyuchevyie kompetentsii kak rezultativno-tselevaya osnova kompetentnostnogo podhoda $\mathrm{v}$ obrazovanii: avtorskaya versiya [Key competencies as a result-based basis of the competence approach in education: author's version]. Moskva: Issledovatelskiy tsentr problem kachestva podgotovki spetsialistov, [in Russian].

Herliand, T. M, Drozich, I. A., Kulalaieva, N. V., Romanova, H. M. ta Shymanovskyi, M. M., 2019. Orhanizatsiia dualnoi formy navchannia u zakladakh profesiinoi (profesiino-tekhnichnoi) : praktychnyi posibnyk [Organization of dual form of education in professional (vocational) institutions: practical manual]. Zhytomyr: Polissia, [in Ukrainian].

Kravets, S. H., Kravets, Yu. I., Derevianko, N. P. ta Oliferchuk, O. H., 2014. Pedahohichni osnovy formuvannia zmistu pidhotovky kvalifikovanykh robitnykiv za intehrovanymy profesiiamy: posibnyk [The Pedagogical Principles of Building the Content of Training of Skilled Workers for Integrated Professions: a Textbook]. Kyiv: Polihrafservis, [in Ukrainian].

Kulalaieva, N. V. ta Gerliand, T. M., 2018. Dualna forma navchannia - zaporuka yakisnoi pidhotovky suchasnoho kvalifikovanoho robitnyka[Dual form of training is the key to qualitative training of a modern skilled worker.]. Profesiinotekhnichna osvita [Vocational Education], 4, s. 40, [in Ukrainian].

Luzan, P. H., 2012. Realizatsiia kompetentnisnoho pidkhodu v profesiinii osviti: tekhnolohichnyi aspekt [Realization of the competence approach in vocational education: technological aspect]. Naukovyi visnyk Instytutu profesiino-tekhnichnoi osvity NAPN Ukrainy. Profesiina pedahohika [Scientific herald of the Institute of vocational education and training of NAES of Ukraine. Professional Pedagogy], 4, s. 5-11, [in Ukrainian].

Luzan, P. H., Yahupov, V. V., Lukianenko, H. I., Piatnychuk, T. V. ta Mykhniuk, M. I., 2015. Modulno-kompetentnisnyi pidkhid u pidhotovtsi kvalifikovanykh robitnykiv budivelnoi ta mashynobudivelnoi haluzei: monohrafiia [Modular competence approach in the training of skilled workers of construction and machine-building branches: monograph]. Kyiv: IPTO NAPN Ukrainy, [in Ukrainian]. 
Oleynikova, O.N., Muraveva, A.A., Konovalova, Yu.V. ta Sartakova, E.V., 2010. Modulnyie tehnologii: proektirovanie i razrabotka obrazovatelnyih programm: ucheb. posobie [Modular technologies: design and development of educational programs: textbook]. Moskva: Alfa-M; INFRA-M., [in Russian].

Pankov D.V., 2003. Orhanizatsiya modulnoi pidhotovky pratsivnykiv u vidpovidnosti z vymohamy rynku pratsi [Organization of modular training of employees in accordance with the requirements of the labor market.]. Problemy inzhenernopedahohichnoi osvity [Problems of engineer pedagogical education], 5, s. 160-166, [in Ukrainian].

Yahupov, V.V., 2014. Modulno-kompetentnisnyi pidkhid do profesiinoi pidhotovky maibutnikh kvalifikovanykh robitnykiv budivelnoi ta mashynobudivnoi haluzei [Modular competence approach to professional training of future skilled workers of construction and machine-building industries]. Naukovyi visnyk Instytutu profesiino-tekhnichnoi osvity NAPN Ukrainy. Profesiina pedahohika [Scientific herald of the Institute of vocational education and training of NAES of Ukraine. Professional Pedagogy], 7, s. 19-26, [in Ukrainian].

Bazyl, L. O., Shatkovska, H. I., Klymenko, M. M., and Radkevych, V. O., 2019. Psychological and pedagogical features of the career growth of vocational education's teachers. Opcion, 35 (Special Issue 23), 763-779, [in English].

\section{Професійна підготовка майбутніх кваліфікованих робітників у закладах професійної (професійно-технічної) освіти на модульно-компетентнісній основі}

\section{Тетяна Герлянд,}

кандидат педагогічних наук, старший науковий співробітник, старший науковий співробітник лабораторії технологій професійного навчання Інституту професійно-технічної освіти НАПН України

\section{Реферат}

Актуальність: для здійснення ефективної особистісної самореалізації майбутнього кваліфікованого робітника система професійної (професійно-технічної) освіти мусить реагувати на зміни, шо відбуваються у сфері праці, економіці, структурі ринку професій, попиті на нові компетентності. Все це вимагає істотного підвищення ступеня гнучкості системи цієї освіти, створення принципово нових форм іiї взаємодії з ринком праці, роботодавцями (соціальними партнерами), для активної їх участі в їі подальшому розвитку.

Meта: здійснити теоретико-методологічне обгрунтування системи професійної підготовки майбутніх кваліфікованих робітників у закладах професійної (професійно-технічної) освіти на засадах модульнокомпетентнісного підходу.

Методи: теоретичний аналіз, вивчення нормативних документів, аналіз навчальних програм - для з'ясування стану розробленості проблеми та визначення напрямів дослідження; порівняння - 3 метою вивчення різних наукових поглядів на проблему; аналіз і синтез - задля розроблення критеріїв та показників готовності майбутніх кваліфікованих робітників до здійснення професійної діяльності на модульній основі; систематизація та узагальнення - для формулювання висновків.

Результати: розкрито істотні характеристики модульно-компетентнісного навчання, охарактеризовано його особливості та основні аспекти, що створюють належні умови для формування ключових компетентностей та успішності навчання майбутніх кваліфікованих робітників, для розвитку їхньої творчої пізнавальної активності й самостійності в умовах модульного оволодіння професійною діяльністю.

Висновки: у здійсненій професійної підготовки майбутніх кваліфікованих робітників на модульно-компетентнісній основі відбувається комплексне засвоєння умінь і знань в рамках формування конкретної компетентності особистості, яка забезпечує виконання певної трудової функції та відображає вимоги сучасного ринку праці.

Ключові слова: компетентність, модуль, модульно-компетентнісний підхід, модульна технологія, професійнотехнічна освіта. 